\title{
To Study the Effect of Aloes (Kumari Ghan) In Puerperium (Sutikawastha)
}

\author{
Vd. Mrs. Swati Vinayak Gaikwad ${ }^{1}$. Dr.Mrs. Jayashree C. Pawase. ${ }^{2}$ \\ ${ }^{1}$ Associate Professor Prasutitantra Streerog Department. \\ ${ }^{12}$ Professor, Prasutitantra Streerog Department.
}

\begin{abstract}
Ayurveda has given utmost importance to puerperium (sutikawastha). During puerperium the body tissue, especially the pelvic tissue reverts back approximately to the pre pregnant state both Anatomically and physiologically. One of the most important retrogressive change is involution of uterus. If uterine involution takes place properly the uterine strength and its function is restored. If the involution is affected adversely it leads to subinvolution. Cleaning of uterus (garbhashayshodhan) has been advised during puerperium as it enhances the involution. In the present study Aloes (kumari ghan) is used for cleaning of uterus (garbhashay shodhan) in puerperium and is found to be very effective in uterine involution.
\end{abstract}

Keywords: Involution of uterus, puerperium, Aloes.

\section{Introduction}

God has blessed woman with strength of procreation that is to give life to a new creation of its own kind. During pregnancy woman bears the stress of growing the foetus at the cost of her own nourishment. She suffers a great stress during the labour process. This stress causes vata vitiation (vata prakop), weakness of various dhatu ,and suppression of digestion (agnimandya). Though puerperium is all a physiological process she has to be cared to get adjusted with these physiological changes. Some particular regimes have been advised in Ayurveda that are termed as puerperial regimes (sutikaparicharya). These regimes incorporate drugs that act on vata dosha ,have cleansing action on uterus, also stimulate digestive system.

Aloes (kumara ghan) is one such drug that helps in cleaning of uterus ,helps in increasing appetite by stimulating digestive system. Aloes is commonly known as kumara ghan or Krishna bole is used since age old time in India as a regime of puerperium .So I planned to study the efficacy of Aloes in involution of uterus in puerperial period.

Aims: To see the effect of ALOES (kumarighan) on involution of uterus.

Objective: To observe the effect of Aloes on lactation, bowel and appetite.

\section{Materials and Methods}

This is an open randomized comparative clinical trial.

The study was carried out on 60 puerperial women who had undergone normal delivery.

No. of pt.

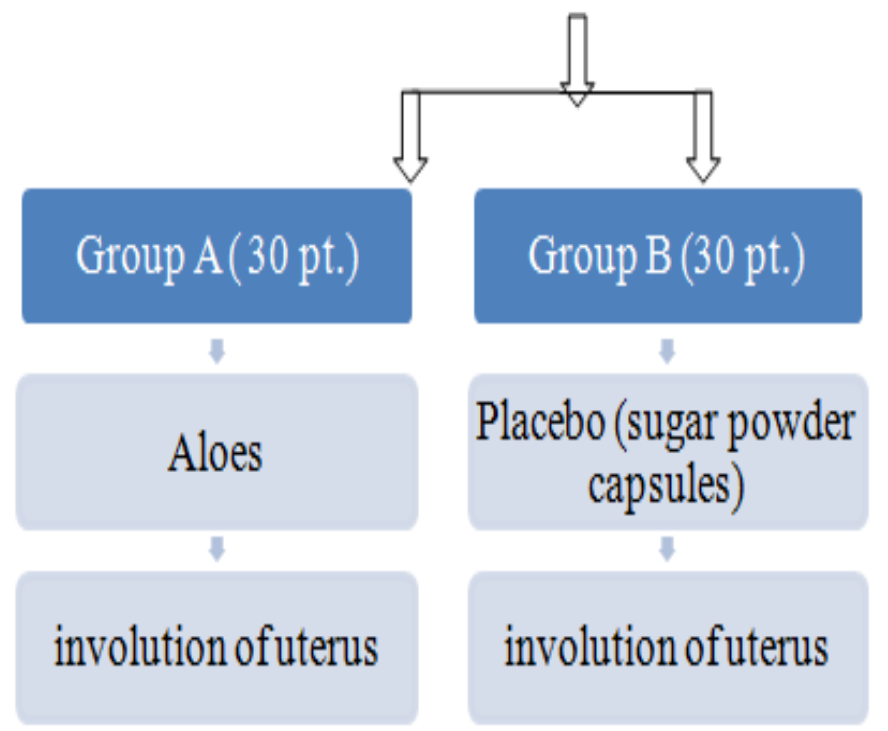




\section{Criteria of Assessment :}

1.Height of uterine involution was measured in both groups at delivery and there after every day for seven consecutive days. Height of uterus was measured with the help of measuring tape in centimeters from pubic symphysis to fundus of uterus, after voiding urine.

\section{Selection criteria:}

Married women between the age group 18 to 35 years delivered normally belonging to all socioeconomic groups.

\section{Exclusion criteria:}

1. Women delivering between 14 to 18 years and above 35 years of age.

2. Women delivered by prolonged labour, preterm birth, caeserian section, Still birth, suffering from eclampsia, preeclampsia, epilepsy, systemic disorder, severe anaemia.

Drug Preparation:

Raw material: Full grown thick leaves of Aloe Vera Barbadenesis.

\section{Method:}

1. The leaves were split with the help of knife to have it divided in to two halves.

2. Then the pulp in the leaves was collected with the help of a scoop.

3. This collected pulp was tied in a cloth and hung overnight to get the juice extracted from it.

4. The extracted juice was then put on low heat to solidify.

5. After it was sufficiently thick, it was made into small tablets and dried in sun to get the livery aloes.

6. The tablets used for study were prepared in one lot.

7. Each tablet weighted $300 \mathrm{mg}$ containing $250 \mathrm{mg}$ of aloes.

8. Gelatin capsules with $200 \mathrm{mg}$ of sugar powder were used as placebo in group B.

\section{Drug administration Kala :}

Apana kala i.e. before meal.

Dose $-500 \mathrm{mg}$ in morning.

$500 \mathrm{mg}$ in evening

Anupana - Lukewarm water.

\section{Observation:}

1. $66.60 \%$ patients in group A had $16-20 \mathrm{~cm}$ of uterine involution at the end of $7^{\text {th }}$ day where as $26.64 \%$ patients in group B had $16-20 \mathrm{~cm}$ involution at the end of $7^{\text {th }}$ day.

2. $63.33 \%$ patients in group A had milk secretions on $2^{\text {nd }}$ day where as $46.66 \%$ patients in group B had milk secretions on $2^{\text {nd }}$ day.

3. Weight of the babies on $7^{\text {th }}$ day in group A was $43.33 \%$, whereas in group B it was seen to be $33.33 \%$.

4. In group A $60.27 \%$ patients passed stool on $2^{\text {nd }}$ and $3^{\text {rd }}$ day of puerperium, while in group B $26.64 \%$ patients passed stool on $2^{\text {nd }}$ and $3^{\text {rd }}$ day of puerperium.

\section{Discussion}

Aloes accelerates the cleansing action of uterine cavity which accelerates the involution of uterus. Involution of uterus must have lead to secretion of pitocin which must have promoted milk secretion. But this study has to be carried out separately. The enhanced weight gain of the babies is the result of early milk secretions. This drug stimulates the digestive system that has promoted early bowel evacuation.

\section{Conclusion}

Aloes is very effective for involution of uterus during puerperium. It also promotes lactation and stimulates digestive system. 